\title{
Bacteriological hazards in camel's meat products
}

\author{
F. A. Khalafalla ${ }^{1 *}$, Zienab M. Niazi ${ }^{2}$, Dalia Y. Mohamed $^{2}$ \\ ${ }^{1}$ Department of Food Hygiene, Faculty of Veterinary Medicine, Beni-Suef University and ${ }^{2}$ Animal \\ Health Research Institute, Dokki- Giza, Egypt.
}

\begin{abstract}
A total of one hundred meat products samples; 20 each of camel's minced meat, burger, rice kofta, frankfurter and luncheon were collected from different supermarkets at Cairo and Giza Cities. All samples were exposed to bacteriological examination and showed that the mean values of aerobic plate count, psychrophiles, coli forms, fecal coli forms, $S$. aureus, and B. cereus in examined camel's minced meat, burger and rice kofta were higher than luncheon and frankfurter. E. coli, Salmonellae, S. aureus and B. cereus, L. monocytogenes were isolated from examined camel's meat products by different percent. The public health significance of the isolated microorganisms as well as suggestions for improving the quality of the camel meat products were discussed.
\end{abstract}

Camel is considered one of the ideal livestock in Egypt. It makes optimal utilization of the meager vegetation and water resources better than any other domestic animal species (El Iraqi, 1996).

Recently, the huge increase of human population create a great demand of easily prepared meal contain high protein, however, meat products are ideal sources of protein, so modern food technology creates numerous and delicious forms of meat product such as kofta, sausage, rice kofta, basterma, luncheon. Camel's meat products are new products appear in the Egyptian markets, the use of camel's meat for sausage eliminated its toughness, make the meat easily curd and itching protein content provides good caloric value.

Raw meat is commonly contaminated with salmonella. Direct infections with salmonella are rarely occurred from raw meat, also occasional cases result from continuous consumption of dishes such as raw sausage. In most cases the infection occurs in post processing contamination of the product. (NRC, 1985)

The exposure of pathogenic E. coli is greater in countries where general standards of hygiene are poor thus the enterotoxogenic E. coli as example are common, and in many cases the major cause of travellar diarrhea in areas where diarrheic E. coli is endemic, it is usually not possible to associate an infection with specific food. Meat products were implicated in many outbreaks in different countries as UK and Romenia (Doyle and Padyhe, 1989).

The mechanism of Listeria pathogenicity are not well understood and only one virulence factor, a heamolysin (listeriolysin $\mathrm{O}$ ), has been fully identified, under the correct circumstance anyone can be infected with Listeria monocytognes, but in most cases people remain symptom free. However, Bacillus cereus and staphylococcal aureus are incriminated to food poisoning organisms in meat and meat product when the condition is favorable to production of toxins which are responsible for the condition of poisoning; the diarrhea and vomiting are the main symptoms of poisoning by the forementioned micro-organisms (Varnam and Evans, 1991).

The data concerning microbiological hazards of camel meat products is low due to unavailable researches handled in the field. Therefore, this work was carried out to assess the microbiological examination of camel meat products (burger, frankfurter, luncheon, minced meat, rice kofta) collected from supermarkets and grocery stores in Cairo and Giza Governorates. Public health significance of isolated microorganisms as well as suggestive hygienic measures were discussed.

\section{Materials and methods}

Collection of samples. One hundred samples of camel's meat products; 20 each of minced meat, burger, rice kofta; frankfurter and luncheon, were collected from supermarkets and grocery stores at Cairo and Giza Governorates. The collected samples were packed, identified and rapidly transferred as possible in ice-box to the laboratory in Animal Health Reference Institute for bacteriological examinations.

\footnotetext{
* Corresponding author. Tel.: +20 082 2322066;

Fax: +20 0822327982

E-mail address: khalafalla@bsu.edu.eg

(Fathy A. khalafalla)
} 
Sample preparation. The technique of samples preparation and serial dilutions were recommended by (ICSMF, 1978).

Bacteriological Examinations.

Determination of Aerobic plate at $30^{\circ} \mathrm{C}$. The pour plate technique for aerobic plate count was preformed according to (ISO, 2003).

Enumeration of psychrophiles. Psychrophiles count was preformed according to technique recommended by (APHA, 1992) was applied.

Most probable number of Coli forms, faecal coli forms and $\mathbf{E}$. coli. The applied technique was the three tubes method (MPN) recommended by( FAO, 1992).

Isolation and identification of $E$. coli biotype $I$ (true faecal type). The isolates were identified microscopically and biochemically according to the methods recommended by (APHA, 1992).

Enumeration of Staphylococcus aureus. The technique of Staphylococcus aureus count was performed according to (AOAC, $2003 \mathrm{a}$ ).

Isolation and Identification of Salmonellae. The procedure for isolation and identification of Salmonellae were conducted according to the (ISO, 2002).

Pre-enrichment in non-selective liquid broth. Twenty five grams of test portion were inoculated into $225 \mathrm{ml}$ of buffered peptone water. Incubation was carried out at $37+1^{\circ} \mathrm{C}$ for $18+2 \mathrm{~h}$.

Enrichment in a selective liquid broth. One $\mathrm{ml}$ of the pre-enrichment was transferred to $10 \mathrm{ml}$ of Rappaport-vassiliadis Soya broth. The inoculated broth tubes were at $43^{\circ} \mathrm{C}$ for $24+3 \mathrm{~h}$.

Plating out on selective agar medium. Each enrichment culture was streaked onto a minimum of 2 selective agars for the isolation of Salmonellae.

A loopful from the inoculated RappaportVassiliadis Soya broth was spreaded on the surface of X LD Agar plates and incubated at 37 $+1^{\circ} \mathrm{C}$ for $24+3 \mathrm{~h}$.

Suspected colonies were picked up for morphological, biochemical and serological identification.

Isolation and identification of Listeria monocytogenes. The technique stated by (FAO, 1992) was applied as follows.

Enrichment of samples. Twenty-five grams from the samples were added to $225 \mathrm{ml}$ Listeria enrichment broth. The contents were blended for 2 minutes then incubated for 48 hours at $30^{\circ} \mathrm{C}$.

Plating on selective agar. A loopful from enriched broth was streaked onto Oxford agar then incubated at $35^{\circ} \mathrm{C}$ for $24-48$ hours. Dark brown or black colonies with a brown halo were picked and streaked on tryptone soya agar (Oxiod CM 131) with $0.6 \%$ yeast extract (Oxoid L 21). The inoculated plates were incubated at $30{ }^{\circ} \mathrm{C}$ for 24 hours. Suspected colonies for Listeria monocytogenes were identified.

Enumeration of Bacillus cereus count. The technique of Bacillus cereus cont was performed according to (AOAC, $2003 \mathrm{~b}$ ).

\section{Results and Discussion}

Aerobic plate count at $30^{\circ} \mathrm{C}$ (mesophiles). From Table (1), it was evident that the mean value of aerobic plate count (mesopiles) of examined minced meat samples was $7 \times 10^{6}+2$ $\mathrm{x} 10^{6}$ organisms/gram. While in examined camel's burger samples; was $6 \times 10^{7}+10^{7}$ organisms/gram. In examined camel's koft samples, the mean value was $2 \times 10^{7}+6 \times 10^{6}$ organisms/gram. The mean count in examined camels' frankfurter samples was $2 \times 10^{5}+3 \times 10^{4}$ organisms/gram while it was $10^{5}+2 \times 10^{4}$ organisms/gram of camel's luncheon samples.

Low figures in minced meat were obtained (Kalalou et al., 2004; Mohamed et al., 2006). High figure in camel's burger was recorded by (Hussein, 2006). Low figure in camel's kofta was stated by (Mahamoud and Ali, 2004) and while high figure was reported by (Hussein, 2006). Nearly similar result in camel's frankfurter was obtained by (Hussein, 2006).

The high aerobic plate count in examined samples of each of camel's minced meat, burger and kofta may be attributed to the neglected sanitary measures during processing, handling and storage as well as the use of low quality ingredients in manufacturing. In addition to use of high contaminated raw material in processing. This held the view reported by (Hussein, 2006; Mahmoud and Ali, 2004).

In this respect, Cano-Munoz, (1992) stated that the failure of protection of non meat ingredients from the contamination with dirt and excreta from rodents and infestation with insects is considered as the import source additional of microbial load to products.

Low aerobic plate count in examined samples of camel's frankfurter and luncheon as compared with other products way is attributed to the temperature of smoking which caused a reduction in numbers of microorganism in the products.

The higher temperature of smoking the lower in counts in final product. This agrees with that mentioned by (Heiszler et al., 1972; Hussien, 2006). 
On the other hand, the casing of the products as frankfurter and luncheon may be protect then from additional contamination after processing as well as had a long shelf - life time as compared with fresh of frozen products.

Aerobic plate count at $7^{\circ} \mathrm{C}$ (psychrophiles). From the present data obtained in Table (1), it was achieved that the mean aerobic plate count at $7^{\circ} \mathrm{C}$ (psychrophiles) of examined camel's minced meat was $3 \times 10^{6}+6 \times 10^{5}$ organisms/ gram; while in camel's burger, it was $6 \times 10^{6}+$ $10^{6}$ organisms/ gram. It was $2 \times 10^{7}+6 \times 10^{6}$ organisms/ gram in camel's kofta samples. The mean counts for each of camel's frankfurter and luncheon were $2 \times 10^{4}+5 \times 10^{3}$ and $2 \times 10^{4}+3$ x $10^{3}$ organisms/ gram, respectively.

Nearly similar result camel's minced meat was obtained by (Mahmoud and Ali, 2004).

Microbial growth in fresh meat is important particularly in the meat industry because it is the main factor associated with the reduction of meat quality, spoilage and subsequent economic losses therefore, it is of basic importance to the manufacture of all processed meat is the selection of proper raw material. Also all ingredients which are added to the meat product must have food grade purity, they should not contained high microbial load, so must be treated according to the highest hygienic standards and this in-agreement with hypothesis mentioned by Mahmoud and Ali, (2004).

psychrophiles microorganisms able to grow within on long chilling storage, however, spoilage organisms grow causing slimness or souring of product.

Coli form and fecal coli forms (MPN). From the obtained results in Table (1), it was achieved that the mean most probable number of coli form in each of camel's minced meat, burger, camel's kofta, frankfurter and luncheon were $2 \times 10^{3}+3$ $\mathrm{x} 10^{2}, 7 \times 10^{3}+10^{3}, 10^{3}+6 \times 10^{2}, 2 \times 16^{2}+30$ and $2 \times 10^{2}+30$ organisms/gram, respectively.

From the same Table, it could be concluded that the mean most probable number of fecal coli form in each of camel's minced meat, burger, camel's kofta, frankfurter and luncheon were $6 \mathrm{x}$ $10^{2}+2 \times 10^{2}, 5 \times 10^{2}+10^{2}, 5 \times 10^{2},+3 \times 10^{2}$, $70+20$ and $40+9$ organisms/gram; respectively.

High figure in camel's minced meat recorded by Mahmoud and Ali, (2004). Nearly similar figures in each of minced meat and kofta were reported by Hussein (2006) while high figures in burger and frankfurter were obtained by Hussien, (2006).
The coli form bacteria are, in general undesirable in food, and their presence in meat products in indicative of sewage contamination and hence of the possible presence of enteric pathogens. This substitutes the hypothesis reported by (Frazier and Westhoff, 1989).

The presence of fecal coli forms may be related to fecal contamination. The organisms can originated from improperly sanitized working surface during dressing of carcasses, therefore, their presence would reflect the degree of sanitation. This agrees with that reported by (Banwart, 1981).

Staphylococcus aureus count. From Table (1), it is evident that the mean Staphylococcus aureus count in camel's minced meat was $2 \times 10^{3}+2 \mathrm{x}$ $10^{2}$ organisms/ gram. While it was $2 \times 10^{3} \pm 4 \times$ $10^{2}$ organisms/ gram camel's burgers. In camel's kofta samples, the mean count was $2 \times 10^{3}+5 \times$ $10^{2}$ organisms/gram. The mean staphylococcus aureus count for each of camel's frankfurter and luncheon was $3 \times 10^{2}+6 \times 10$ and $3 \times 10^{2}+5 \times$ 10 organisms/gram, respectively.

Nearly similar results in minced meat and kofta were mentioned (Mohamoud and Ali, 2004; Mohamed et al., 2006).

High figures in each of rice kofta, burgers and frankfurter were reported (Hussien, 2006).

The contamination of camel's meat products with staphylococcus spp. may be attributed to people working in meat processing plant as their hand were found to be highly contaminated as well as during steps of manufacturing, horizontal contamination to final product may occur, which may be highly significant for safety of meat products. This agrees with that stated by (Shovgaard, 1995; Schlegelova et al., 2004).

Bacillus cereus count. The present data recorded in Table (1); it was achieved that, the mean values of Bacillus cereus counts were $5 \mathrm{x}$ $10^{3}+10^{3}, 2 \times 10^{3}+5 \times 10^{2}, 6 \times 10^{3}+4 \times 10^{3}, 2$ $\times 10^{2}+30$ and $5 \times 10^{2}+10^{2}$ organisms/ gram in camels' minced meat, burger, rice koft, frankfurter and luncheon; respectively.

Nearly similar figure was obtained by (Mohamed et al., 2006). High figure was recorded by (Mahmoud and Ali 2004).

The contamination of camel's meat products with bacillus cereus may be attributed to very bad and very low hygienic conditions through out the whole processing, handling; packaging and storage. This held the view reported by (Mohamed et al., 2006).

Isolated microorganisms. 
Escherichia coli. From the present data in Table (2), it is evident that Escherichia coli could be isolated from camel's burger, frankfurter, luncheon, mined meat and rice kofta with incidences $45 \%, 10 \%, 10 \%, 30 \%$ and $20 \%$ respectively.

High figure was detected in rice kofta by (Mohamoud and Ali, 2004) while low figure was reported (Hussien, 2006). Low figure in frankfurter was reported (Hussien, 2006). Low figures in each of burger an rice kofta was reported by Ouf, (2004) while Nearly similar results in minced meat.

From data illustrated in Table (3), it could be concluded that, the serotypes of E.coli from minced meat were isolated as follows $\mathrm{O}_{1}, \mathrm{O}_{126}$, $\mathrm{O}_{127}$ while from burger, the serotypes of $E$. coli were isolated as follows $\mathrm{O}_{1}, \mathrm{O}_{27}, \mathrm{O}_{126}, \mathrm{O}_{127}, \mathrm{O}_{153}$ and from rice kofta the serotypes of E.coli were as follows $\mathrm{O}_{126}, \mathrm{O}_{153}$. While from frankfurter the serotypes of E.coli were isolated as follows $\mathrm{O}_{27}$ and from luncheon the serotypes of E.coli were $\mathrm{O}_{126}, \mathrm{O}_{127}$.

On the other hand, the serotypes of salmonella were isolated from minced meat as follow Salmonella entriditis and Salmonella typhimurium while from burger serotypes of salmonella were isolated Salmonella typhimurium.

Escherichia coli is the most predominant fecal coli forms. The main habitat of E. coli is the intestinal tract of man and worm blooded animals, it is believed by some microbiologists that only the presence of $E$. coli is indicative of fecal contamination of food. Hence, there is a close association between $E$. coli, fecal material and possible other enteric pathogen (FAO/WHO, 1991).

Salmonellae. From Table (2); it was achieved that salmonellae could be isolated from each of camel's burger and minced meat; each constituting $20 \%$ and $25 \%$ respectively. On contrary it could be failed to detect in either of frankfurter, luncheon and rice koft.

High figures of Salmonellae in each of burger and rice kofta could be detected by (Hussien, 1996) while nearly similar result was found in frankfurter. Low figure in salmonellae could he reported in minted meat burger (Ouf, 2004) while High figure was reported in rice kofta.

The contamination with Salmonellae is associated with enteric contamination. The reservoir of S. typhimurium is rodents; flour of plant and equipment may be contaminated with faeces of mice and so contaminated the products and this is in-accordance with that reported by (Siam et al., 1995).

The outbreaks of Salmonellosis follow from inadequate cooking, mishandling and recontamination. Raw meats can act as a source of cross contamination to final products or other ingredients in processing plants. This confirmed by that reported by (ICMSF, 1998).

Listeria monocytogenes. From present data in Table (2), it was evident that Listeria monocytogenes could be isolated form camel's burger, minced meat and rice koft, each constituting $15 \%, 20$ and $30 \%$ respectively. Neither camel's frankfurter nor luncheon could be isolated Listeria monocytogenes.

Listeria monogytogenes is widely distributed in nature and its association with meat is well documented. The pathogen was implicated in several serious food-bone out breaks (Chen and Hoover, 2003)

Staphylococcus aureus. Table (2) was revealed that Staphylococcus aureus coagulase positive could be isolated from camel's burger, frankfurter, luncheon, minced meat and rice koft with incidences $45 \%, 15 \%, 25 \%, 50 \%$ and $45 \%$ respectively.

High figure could be isolated from rice kofta (Ouf, 2004; Mahmoud and Ali, 2004). Low figure was detected by (Hussien, 2006) However; Franksen et al., (1969) could not isolate any of pathogenic microorganisms from frankfurter. Low figures in each of burger and minced meat was reported by (Ouf, 2004).

The source of contamination to meat products during manufacturing may be attributed to meat handlers and equipment. However skin upper respiratory tract of worker's dust and moust aure droplets have etiological significance in causing food borne illness, Moreover, the contaminated water may be attributed to add cross-contamination during processing. This held the view reported by ( Hegazi, 1995; Siam et al., (995).

In this respect, Sokari and Anozie, (1990) stated that the high level of staphylococcus contamination may be resulted from cross contamination, reflecting excessive hand contact with the foodstuffs.

On the other hand, Park et al., (1994) stated that staphylococcal food poisoning caused by ingestion of enterotoxins produced in food by some strain of $S$. aureus. Growth of enterotoxigenic strains of $S$. aureus population of at least $5 \times 10^{5}$ cells/g of food is generally 
Table (1): Statistical analytical results of bacterial counts in the examined camel's meat product samples (mean \pm S.E.) $(n=20)$.

\begin{tabular}{|c|c|c|c|c|c|}
\hline & $\begin{array}{c}\text { Camel's } \\
\text { minced meat }\end{array}$ & Camel's burger & $\begin{array}{c}\text { Camel's rice } \\
\text { kofta }\end{array}$ & $\begin{array}{c}\text { Camel's } \\
\text { frankfurter }\end{array}$ & $\begin{array}{c}\text { Camel's } \\
\text { luncheon }\end{array}$ \\
\hline Aerobic plate count & $7 \times 10^{6} \pm 2 \times 10^{6}$ & $6 \times 10^{7} \pm 1 \times 10^{7}$ & $2 \times 10^{7} \pm 6 \times 10^{6}$ & $2 \times 10^{5} \pm 3 \times 10^{4}$ & $1 \times 10^{5} \pm 2 \times 10^{4}$ \\
\hline Pyschrophilic count & $\begin{array}{l}3 \times 10^{6} \pm 6 \times \\
10^{5}\end{array}$ & $6 \times 10^{6} \pm 10^{6}$ & $2 \times 10^{7} \pm 6 \times 10^{6}$ & $2 \times 10^{4} \pm 5 \times 10^{3}$ & $2 \times 10^{4} \pm 3 \times 10^{3}$ \\
\hline Coli form (MPN) & $2 \times 10^{3} \pm 3 \times 10^{2}$ & $7 \times 10^{3} \pm 10^{3}$ & $10^{3} \pm 6 \times 10^{2}$ & $2 \times 10^{2} \pm 3 \times 10$ & $2 \times 10^{2} \pm 3 \times 10$ \\
\hline Fecal coli form (MPN) & $6 \times 10^{2} \pm 2 \times 10^{2}$ & $5 \times 10^{2} \pm 10^{2}$ & $5 \times 10^{2} \pm 3 \times 10^{2}$ & $7 \times 10 \pm 2 \times 10$ & $4 \times 10 \pm 9$ \\
\hline S. aureus count & $2 \times 10^{3} \pm 2 \times 10^{2}$ & $2 \times 10^{3} \pm 4 \times 10^{2}$ & $2 \times 10^{3} \pm 5 \times 10^{2}$ & $3 \times 10^{2} \pm 6 \times 10$ & $3 \times 10^{2} \pm 5 \times 10$ \\
\hline B. cereus count & $5 \times 10^{3} \pm 1 \times 10^{3}$ & $2 \times 10^{3} \pm 5 \times 10^{2}$ & $6 \times 10^{3} \pm 4 \times 10^{3}$ & $2 \times 10^{2} \pm 3 \times 10$ & $5 \times 10^{2} \pm 1 \times 10^{2}$ \\
\hline
\end{tabular}

Table (2): Incidence of isolated microorganisms from examined camel's meat product samples.

\begin{tabular}{|c|c|c|c|c|c|c|c|c|c|c|}
\hline \multirow{2}{*}{ Sample } & \multicolumn{2}{|c|}{ E. coli } & \multicolumn{2}{|c|}{ Salmonellae } & \multicolumn{2}{|c|}{ L. monocytogenes } & \multicolumn{2}{|c|}{ S. aureus } & \multicolumn{2}{|c|}{ B. cereus } \\
\hline & No. & $\%$ & No. & $\%$ & No. & $\%$ & No. & $\%$ & No. & $\%$ \\
\hline Burger & 9 & 45 & 4 & 20 & 3 & 15 & 5 & 45 & 5 & 25 \\
\hline Frankfurter & 1 & 5 & 0 & 0 & 0 & 0 & 6 & 30 & 2 & 30 \\
\hline Luncheon & 2 & 10 & 0 & 0 & 0 & 0 & 4 & 20 & 4 & 20 \\
\hline Minced meat & 6 & 30 & 5 & 25 & 4 & 20 & 2 & 10 & 6 & 10 \\
\hline Rice koftakofta & 4 & 20 & 0 & 0 & 6 & 30 & 9 & 45 & 9 & 45 \\
\hline
\end{tabular}

Table (3): Serotyping of isolated E.coli.

\begin{tabular}{lccccc}
\hline Serotype & Minced meat & Burger & Rice kofta & Frankfurter & Luncheon \\
\hline O1 & 2 & 1 & - & - & - \\
O27 & - & 1 & - & 1 & - \\
O126 & 1 & 3 & 2 & - & 1 \\
O127 & 3 & 2 & - & - & 1 \\
O153 & - & 2 & 2 & - & - \\
\hline
\end{tabular}

Table (4): Serotyping of isolated Salmonellae.

\begin{tabular}{lccccc}
\hline Serotype & Minced meat & Burger & Rice kofta & Frankfurter & Luncheon \\
\hline Salmonella typhimurium & 4 & 4 & - & - & - \\
Salmonella entriditis & 1 & - & - & - & - \\
\hline
\end{tabular}

considered necessary for production of sufficient amount of enterotoxin to cause intoxication if the food is consumed.

Bacillus cereus. Table (2) revealed that bacillus cereus could be isolated from camel's burger, frankfurter, luncheon, minced meat and rice kofta each constituting 25\%, 30\%, 20\%, $10 \%$ and $45 \%$, respectively.

High figure was detected in rice kofta by (Mahmoud and Ali, 2004). Low figure in each of burger and rick kofta were reported (Ouf, 2004) as well as high figure in minced meat.

The source of bacillus cereus in meat products may be attributed to very bad hygienic conditions through out the whole the whole processing, handling and storage. In addition to that non meat ingredients as rice in considered as the main source for its presence. This agrees with that reported by (Mahmoud and Ali, 2004; Mohamed et al., 2006).

From the present data, it could be concluded that the high microbial load may be due to poor hygiene during manufacturing, inadequate temperature of storage, bacterial load of the meat, incorrect temperature of processing, thawing as well as prolonged holding of the semi-manufacturing product.

Finally, to improve the quality of camel meat products to be safe for human consumption, the following recommendation should be adopted:

Education programs should be imposed for processors and handlers.

Luncheon should be kept in good ventilated place away from sunlight and also temperature and humidity should be properly controlled

Application food safety management system (ISO 22000).

\section{References}

American Public Health Association (APHA) (1992): Compendium of Methods for the Microbiological Examination of Foods. $3^{\text {rd }}$ Ed. APHA Technical Committee on Microbiological for food. Washington, D. C., USA Association of Official Analytical chemists, AOAC (2003a): Surface plating Method for Isolation and 
Enumeration of Staphylococcus aureus in Food. AOAC Official Method 975. 55.

Association of Official Analytical chemists AOAC (2003) : Bacillus cereus in food, Enumeration and Confirmation Microbiological Methods. AOAC Official Method 980. 31. B anwart, J. F. (1981): Indicator Organisms. In Basic Food Microbiology. The AVI Publishing Company Inc. Westport Connectiut, USA.

Cano- Munoz, G. (1992): Guidelines for slaughlering meat cutting and further processing. FAO Animal Production and Health Paper, United Nation.

Dolye, M. P. and Padyhe, V.V. (1989): Escherichia coli. In Food borne Bacterial Pathogens, Dolye, (Ed). Marcel Dekker: New York and Basel. Standards frozen frankfurter, hotdog and sausage No.3492- 2005. Egyptian Organization for Specification and Quality Control. Ministry of Industry, Egypt.

El Iraqi S. M. (1996): Camel News letter. The camel applied research and development network. First meeting of the general Assembly Damascus. The Arab center for studies of arid zones and dry land, Syria.

El-Nawawi, F. A. and Nouman, T. M. (1981): Investigation ints the microbiological quality of fresh raw sausage. Fleischwirtschaft, 61:6.

FAO (1992): Manual of food and quality control. 4. Microbiological analysis. Food and Agriculture Organization of the United Nation, Rome.

FAO/WHO (1991): WHO surveillance programme for control of food borne Infections and Intoxications in Europe, Inst. Vet. Med., $2^{\text {nd }}$ Report, Berlin (West Germany).

Fraizer, W. C. and Westhoff. D. C. (1989): Food Microbiology. $4^{\text {th }}$ Ed. McGraw-Hill Company, Inc. New York - Toronto, London.

Franksen, H.; Hadlok, R. and Bartels, H. (1989): Setting standards for bacterial counts in frankfurter type sausages. Workes, 15: 107

Heiszler, H. G.; Kraft, A. A., Rey, C. R. and Rust, R. E. (1972): Effect of time and temperature of smoking on microorganism in Frankfurters. J. Food Sci., 37: 845.

Hussien, S. F. M. (2006): Quality of some Camel's meat products. M. V. Sc., Thesis, Fac. Vet. Med. Cairo Univ, Egypt.

Ibrahim, A. (1981) : Sanitary Condition of locally produced (Hamburger) M. V. Sc., Thesis, Fac. Vet., Med., Cairo University, Egypt.

International committee of microbiological Specification for Foods ICMSF (1978): Microorganisms in Foods. Their significance and methods of enumeration, $2^{\text {nd }}$ Ed. University of Toronto, Press, Toronto and Buffalo, Canada. International Commission on Microbiological Specifications for Foods, ICMSF (1998): Microorganisms in food. Microbial ecology of foods commodities. pp. 2427. Blackie Academic and Professional, London, New York, Tokyo, Melbourne, Madreas.

ISO, 6579 (2002): Microbiology of food and Animal feeding staff. Horizontal Method for detection of Salmonellae. International organization for Standardization. J. Food Prot., 55: 4.

ISO, $48333^{\text {ed }}$ edition (2003): Microbiology of food and Animal feeding staff. Horizontal Method for the enumeration of microbrganisms - lolony - count technique at $30^{\circ} \mathrm{C}$.

Kalalou (2004): Extending shelf life of fresh minced camel meat at ambient temperature by Lactobacillus dlbrueckii subsp. Delbrueckii Electronic J. Biotechnol., 7(3): 7173458.

Mahmoud, Y. El. A. and Ali, F. H. M. (2004): Risk assessment of rice Kofta formed from cameal meat. Assiut Vet. Med. J., $50: 66$

Mohamed, W. S; Hassan, H. F. and Mohamed, M. M. (2006): The effect of safe irradiation on the Bacteriological and chemical state of some Camel's meat products. Assiut Vet. Med. J. 52.

NRC (1985): An Evaluation of the Role of Microbiological Criterin for Foods and Food Ingredients. National Academy. Press: Washington DC.

Ouf, J. M. (2004): Microbiological evaluation and mycotoxin residues in some frozen camels meat products. Vet. Med. J., $52: 213$.

Park, C. E., Akhtar, M. and Rayman, M. K. (1994): Evaluation of commercial enzyme immunoassay kit (RIDASCREEN) for detection of staphylococcal enterototoxins A, B, C, D, and E in foods. Appl. Environ. Microbiol., 60: 677. Listeria, Listeriosis and Food Safety. Marcel Dekker, Inc, New York.

Schlegelova J.; Napravnikova E.; Dendis M.; Horvath R.; Benedik J.; Babak V.; Klimova E.; Navratilova P.; Sustackova A. (2004): Beef carcass contamination in a slaughterhouse and prevalence of resistance to antimicrobial drugs in isolates of selected microbial species. Meat Sci., 66: $557-565$.

Siam, M.; Hamed, O.; Ghoneim, N. and Wahid, W. (1995): Zonnoses for veterinary students and practitioners. $1^{\text {st }}$ Ed., Cairo University, Egypt.

Sokari, T.G. and Anozie, S.O. (1990): Occurrence of enterotoxin producing strains of Staphylococcus aureus in meat and related samples from traditional markets in Nigeria. J. Food Prot., 53:1069.

Varnam, A. H. And Evans, M.C. (1991): Food Borne Pathogens. An illustrated text, chapter. 13, pp 267. England, Wolfe publishing Ltd. ISBN 0 7234, 1512, 8.

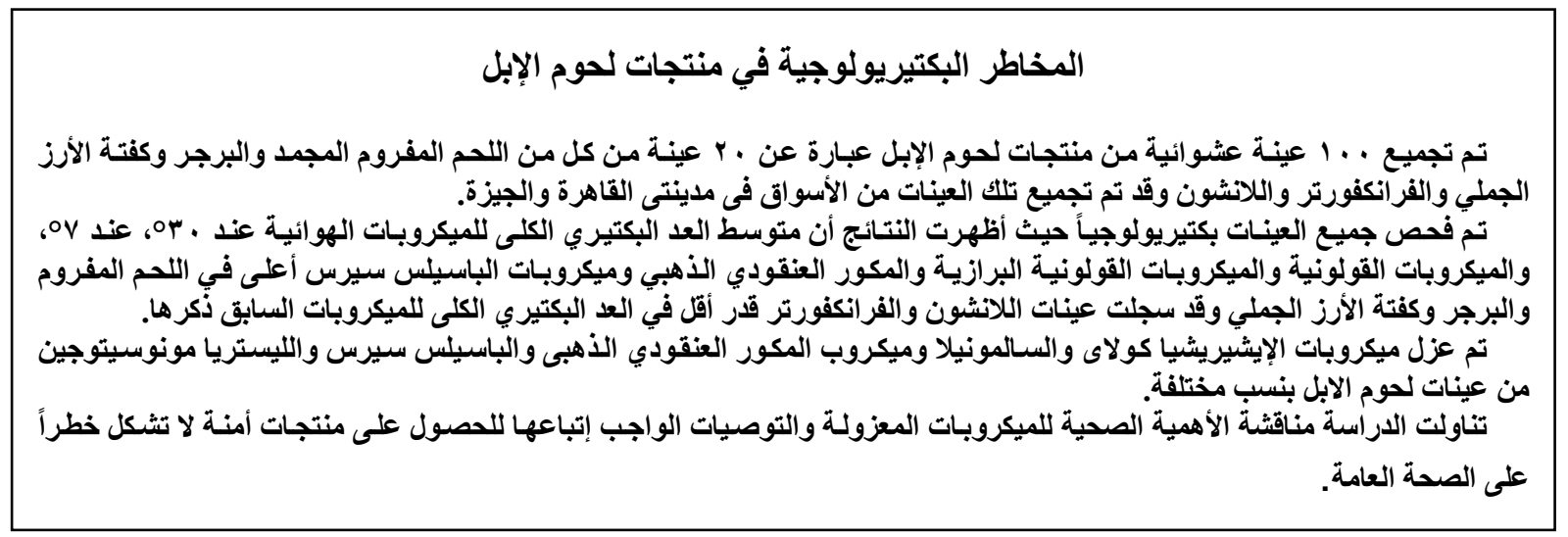

